A History of Scottish Philosophy 



\section{A History of Scottish Philosophy}

Alexander Broadie

EDINBURGH UNIVERSITY PRESS 
(C) Alexander Broadie, 2009, 2010

First published in hardback in 2009 by

Edinburgh University Press Ltd

22 George Square, Edinburgh

This paperback edition published 2010

Typeset in 11/13pt Adobe Sabon by Servis Filmsetting Ltd, Stockport, Cheshire, and printed and bound in Great Britain by CPI Antony Rowe, Chippenham and Eastbourne

A CIP record for this book is available from the British Library

ISBN 9780748616282 (paperback)

The right of Alexander Broadie to be identified as author of this work has been asserted in accordance with the Copyright, Designs and Patents Act 1988. 